\title{
The London Patient
}

\author{
Timothy Ray Brown
}

$\mathbf{I}_{\mathrm{r}}^{\mathrm{T}}$ T IS DIFFICULT TO EXPLAIN the solitude associated with being the only person ever cured of HIV. Although I have many friends and an amazing partner, being the only example that HIV can be cured can make you feel just a little isolated and alone. That all changed with the announcement last year that others may have also been cured of HIV. Like my previous commentaries, I provide some insights into how being cured of HIV impacts my life. ${ }^{1-3}$ The focus of this article will be my experiences around learning of the existence of a second person most likely cured of HIV, my contact with this person and the significance of at least one further similar patient, and hopefully more cures of HIV using very similar methods.

I first heard about this person from Tweets from my friend, Michael Louella, who is the main publicist for the NIH (U.S. National Institute of Health) Martin Delaney Collaboratory Group, Defeat HIV. The lead location of this group is the Fred Hutchinson Cancer Research Center (The Hutch) in Seattle Washington. Michael told me that I should go to Seattle for the Conference on Retroviruses and Opportunistic Infections (CROI) because at that time he was hoping that another person possibly cured of HIV in London would also be there and it would be exciting to get both of us together at the meeting. Before I flew to Seattle, I began to receive calls from several media outlets asking for my thoughts on this yetto-be released news.

I arrived in Seattle on Saturday, March 2, 2019 without my partner, Tim, and took the light rail to a downtown hotel for a preconference HIV cure meeting where I spent the rest of the afternoon. Michael informed me of my marching orders for the rest of my stay there and more information about this other "cured" patient and then I went to my hotel in downtown Seattle to check in.

The next morning after a NBC news interview, I went to the Seattle Public Library downtown branch for the main Toward an HIV Cure preconference meeting. I gave several more interviews before the actual meeting began. I sat next to my friend, Professor Anne Marie Wenzing of the University of Utecht in the Netherlands, one of the key investigators for IciStem (icistem.org), a collaborative project to guide and investigate the potential for HIV cure in $\mathrm{HIV}$-infected patients requiring allogeneic stem cell transplantations for hematological disorders. On the other side of me sat Professor Monique Nijhuis also from the University of Utrecht, another key investigator with IciStem, and during the day I also sat with Professor Ravindra Gupta, another investigator with the same group but based in London. Professor Gupta is the lead physician of the so-called "London Patient."

Scientists had dubbed me the "Berlin Patient" not because I might be German, which I am not, or because I lived in Berlin, which I did, but because of the city where the procedure that cured me of HIV took place. It is just a way to identify well-publicized cases in the medical news. Both Professor Monique Nuijuis and Professor Ravindra (Ravi) Gupta spoke in the preconference meeting, Monique gave a background on this method to cure HIV and Ravi specifically on the London Patient for whom he was the chief performing doctor as it related to this case. While he spoke, Anne Marie and I agreed that we think this patient really is cured of HIV. At the time of the announcement at CROI on March 5, 2019, the London Patient had been off of ARVs (antiretroviral medication) for a period of 18 months.

I gave two more interviews on Monday and had dinner with a good friend of mine from Chicago. The next day was the day of the big announcement. I went into the large conference room where Dr. Gupta would present the case of the London Patient. Outside of the conference room, I received a call from the London Times and told the reporter that I am really excited to finally have a new sibling added to my too tiny family of which I was the only member. I told her as I told all reporters covering this story that this, like my case, should not be seen as THE CURE for HIV and that brilliant medical scientists are working on other methods to cure HIV.

These methods need to be more practical, less expensive, scalable, and not require donors who are homozygous for the mutation in CCR5 that renders them highly resistant (nearly immune) to HIV. CCR5 is a protein that is normally part of the surface of the CD4 T cell. HIV uses CCR5 as a doorway to enter into the said CD4 cell to infect it, thus allowing it to replicate and multiply. People with this good mutation from both parents are CCR5 delta 32, making them highly resistant to HIV. Unfortunately, only $1 \%$ of northern Europeans carry this mutation from both parents (called homozygous CCR5 delta 32). People who carry only one copy from one parent (called heterozygous CCR5 delta 32) have less resistance to HIV. Because it is not as simple as finding the right blood type for a patient but also a correct tissue type or human leukocyte antigen match, finding a correct match from a donor bank can prove extremely difficult. Because these very rare matches are more likely in the same heritage (ethnic) groups and is only found in northern Europeans, this leaves out the majority of the earth's population. Although I am very excited about every single person who becomes cured of this

Palm Springs, California. 
virus, much more must to be done to find further methods to cure many more people living with HIV around the world.

Once I finished my interviews, I went back into the auditorium and listened to Professor Gupta's presentation. Since this story had been embargoed, this presentation was originally meant to be the first announcement of this case to the public. However, rumor had it that a newspaper in India that had mixed up the dates because they were nearly a day ahead of Seattle ran the story a day earlier, and other publications and news agencies around the world followed suit. After Ravi's presentation, a female scientist asked the question, which also interested me greatly. The question was whether any biopsies had been performed up to that time on the London Patient. The professor responded that none had been done yet. Ravi confirmed this in a subsequent private conversation I had with him. In my case, once I revealed myself to the public and moved to San Francisco, I allowed and welcomed any biopsies doctors and researchers wanted to perform. I wanted to help with research to further assist research plus I wanted to prove to myself that I am really rid of this virus from my entire body. Nobel Laureate Francoise Barré-Sinoussi's strong insinuation that I had more than a functional cure that means I no longer need to rely on ARVs but a sterilizing cure, meaning that HIV is absent from my entire body, elated me.

I can certainly understand why the London Patient may not have wanted to have biopsies performed. The editor in chief of this journal told me several months ago that no biopsies had been performed yet. I always advocate for patient choice in such questions. I personally believe that people have the full right to make informed and educated choices about anything affecting their own bodies. For example, I made the decision in conjunction with my former partner Michael to stop taking my ARVs. Although I asked the designer of the study, Dr. Gero Hütter, I knew I was making a decision affecting my own life, and I believe it was ultimately my decision to make. I am not sure what lies behind the lack of biopsies at that point in time. I believe that eventually biopsies will be performed on the London Patient.

During the conference, Professor Gupta and a man who introduced himself as the London Patient's social worker asked me if I would be interested in being in contact with the London Patient. I made it very clear that I was interested. Several weeks later, I received an e-mail from the London Patient with several questions. Someone had told me that the London Patient was not comfortable having any information about his personal life revealed and although I had heard rumors about him, I made an extreme effort not to reveal anything I thought I knew about him and his familiar situation.

Obviously I was extremely careful. I answered his first question but it took me a long time to get any further questions answered, so I suggested that we do a video call. Within a couple of weeks, he wrote to me saying that he wanted to use WhatsApp to talk by voice only but without video because he was not ready to reveal his image to anyone outside of his medical team, even to me. I completely understand because it took me even longer to come out to the media, revealing my name and image to the public. I feel that he can do that once he really feels ready. Like he told me, once he has come out publicly, there is absolutely no taking it back. What happens once he is out will be a huge factor in his entire life.

We have been able to have two WhatsApp calls. I am not able to reveal anything that we discussed in the calls beyond that he would like to meet me in person once he has come out with his name and image. I cannot wait to be able to give my brother a huge hug! None of us can know for certain what the effect this will have on the HIV cure world nor what it will mean for the study and treatments of HIV in general.

The event of another patient most likely cured and the potential for more of them prove that my case is not just a singular occurrence and prove further that HIV CAN BE CURED. It is extremely important to me not to give patients, their loved ones, or the general public false hope. Unfortunately, true stories about a second and possibly more may do just that. People may hear about my case and the others and think these events of HIV cure means that HIV is no longer a health threat. HIV is still a huge problem, particularly in the developing world. Furthermore, we are discovering negative long-term effects on people whose HIV is undetectable and we need further methods for cures to eliminate the virus from the entire world. The achievement of a second person cured of HIV is a major event that moves us one step closer to being able to help people living with HIV to live a normal and productive life.

\section{Author Disclosure Statement}

No competing financial interests exist.

\section{Funding Information}

No funding was received for this article.

\section{References}

1. Brown TR: I am the Berlin patient: A personal reflection. AIDS Res Hum Retroviruses 2015;31:2-3.

2. Brown TR: Don't let funding caps to NIH researchers harm highly collaborative HIV cure research. AIDS Res Hum Retroviruses 2017;33:iv.

3. Brown TR: Timothy Ray Brown's continuing activism toward curing HIV. AIDS Res Hum Retroviruses 2018;34: 9-11.

Address correspondence to: Timothy Ray Brown PO Box 4295

Palm Springs, CA 92263-4295

E-mail: tscma369@gmail.com 